\title{
Valuation of Upstream Oil and Gas Projects using Discounted Cash Flow Methods
}

\author{
Case Study: "AAX" Oil Field Development Project, "NW NTX” Working Area
}

\author{
Zarpani \\ Magister Management - Faculty of Economic and Business \\ Universitas Padjadjaran \\ Bandung, Indonesia \\ zarpani@gmail.com
}

\begin{abstract}
The objectives of this study are to valuing the interest in the project development of the "AAX" oil field, "NW NTX" working area which is currently held by "AX" limited and "STX" Limited as contractor under the terms of Production Sharing Contract (PSC) with the Indonesian government, represented by Special Task Force for Upstream Oil and Gas Business Activities. Sluggish global economic downturn and low oil prices lately caused a lot of upstream oil and gas industry to reduce or even stop investing. Therefore do the valuation of the interest value of this project that has been in the development stage. Valuation using the Discounted Cash Flow (DCF) methods version of government rules on the submission of Plan of Development (PoD) and modified version use the long-term forecast of crude oil prices issued by OPEC and considered additional risk based on project conditions. The sensitivity analysis was performed on the results of calculations to determine the sensitivity of interest with respect to changes in input variables. The results of both valuation models show that interest in the project is positive and net cash flow present value during the production period is positive every year. The modified DCF model generate a lower value than the DCF model PoD because of using Minimum Attractive Rate of Return (MARR) that is higher. The result of sensitivity analysis shows that the interest in the project is very sensitive to changes in crude oil prices.
\end{abstract}

Keywords - Discounted cash flow, Interest, Sensitivity analysis, Minimum attractive rate of return

\section{INTRODUCTION}

Upstream oil and gas project is an industry that is dealing with high uncertainty. Basically source of uncertainty consists of technical uncertainty and market uncertainty. Challenges from the technical side, among others, was the successful discovery of economical reserve during the exploration stage and the selection of the technology used in the development stage. Market uncertainty associated with the movement of the global economy affects the price of crude oil, such as supply and demand, availability of alternative energy resources and geopolitical conditions of factors, especially in the Middle East.

Technical uncertainty in the exploration stage is much greater than the exploitation stage. In the exploitation stage, the plan of production rate has been able to be estimated by reservoir engineers use the data results of exploration activities $^{1}$.

Organization of the Petroleum Exporting Countries OPEC, in the Monthly Oil Market Report, published January 2016, shows that in 2014 and 2015 has been an oversupply of crude oil in the market so that the prices falls. In 2016, OPEC expects to balance the demand and supply of world oil production rate of $31.65 \mathrm{MMbbl} /$ day (Mile mile barrels/day or million barrels/day), as presented in Table I

TABLE I. REALIZATION OF SUPPLY AND DEMAND OF OIL IN 2014-2015 AND FORECAST 2016 (IN MMBBL/D) ${ }^{2}$

\begin{tabular}{|l|l|l|l|}
\hline Year & 2014 & 2015 & 2016 \\
\hline Demand & 91,38 & 92,92 & 94,17 \\
\hline Non OPEC Supply & 55,64 & 56,87 & 56,21 \\
\hline OPEC NGLs + Others Supply & 6,00 & 6,15 & 6,32 \\
\hline OPEC Supply & 30,77 & 31,85 & 31,65 \\
\hline Balance & 1,03 & 1,94 & 0,01 \\
\hline
\end{tabular}

Upstream oil and gas industry which sluggish recently has caused oil and gas companies reassessment of their projects. Many of them have laid off employees and shut down their projects that are considered less economical. ${ }^{3,4}$

Therefore, this study aimed to evaluate one of the projects upstream oil and gas in Indonesia, namely development of "AAX" oil field in the "NW NTX" working area (furthermore referred to the "AAX" oil field project). The valuation conducted using Static Discount Cash Flow methods (PoD version and modified version of discount cash flow methods).

\section{LITERATURE REVIEW}

\section{A. Static Discounted Cash Flow (DCF) Methods}

The basic concept of valuations at DCF methods in assessing an asset based upon its ability to generate future cash flow, afterwards the cash flow is discounted into present value (Net Present Value - NPV) using a discount rate that reflects characteristics the risks of such assets ${ }^{5}$. The discount rate is commonly referred the hurdle rate or the minimum attractive rate of return (MARR). So the DCF method uses a single 
discount rate to compensate for the risk of investment which is a combination of risk on the declining value of money as a result of the passage of time (time value of money) and the risk factors due to the uncertainty of future cash flows.

Static DCF equation to calculate NPV using MARR as the discount rate is following:

$$
N P V=\sum_{t=0}^{T} \frac{\text { NCFt }}{(1+\text { MARR })^{t}}
$$

Where,

$N C F_{t}=$ Net cash flow at any time period $(\mathrm{t})$ in years

MARR = the minimum attractive rate of return

Value is frequently used as MARR in investment is derived from the firm" weighted average cost of capital (WACC). The WACC was the minimum return that creditors, owners, and other capital providers requested for the investment, which is calculated by the following equation:

$$
\mathrm{WACC}=\frac{\mathbb{D}}{\mathbb{D}+\mathbb{E}} \mathrm{K}_{\mathrm{d}}(1-\mathrm{T})+\frac{\mathbb{E}}{\mathbb{D}+\mathbb{E}} \mathrm{K}_{\mathrm{e}}
$$

Where,

$\frac{\mathbb{D}}{\mathbb{D}+\mathbb{E}} \quad=$ percentage of debt in the the company's capital

$\mathrm{K}_{\mathrm{d}} \quad=$ cost of debt

$\mathrm{T}=$ company's tax rate

$\frac{\mathbb{E}}{D+E} \quad=$ percentage of equity in the company's capital

$\mathrm{K}_{\mathrm{e}} \quad=$ cost of equity

The cost of equity can be determined by the capital asset pricing model (CAPM), by the following equation:

$$
R_{j}=R_{f}+\beta\left(R_{m}-R_{f}\right)
$$

Where,

$$
\begin{array}{ll}
\mathrm{R}_{\mathrm{j}} & =\text { the expected return on the capital asset } \\
\mathrm{R}_{\mathrm{f}} & =\text { risk free rate } \\
\left(\mathrm{R}_{\mathrm{m}}-\mathrm{R}_{\mathrm{f}}\right)= & \text { risk market premium } \\
\beta \quad & \text { the sensitivity of the expected excess asset } \\
& \text { returns to the expected excess market returns }
\end{array}
$$

MARR of upstream oil and gas projects supposed to take into account the additional discount rate related projects risk of upstream oil and gas project and suggested MARR upstream oil and gas project in Indonesia is calculated using the following equation ${ }^{6}$ :

$$
\text { MARR }=\text { WACC }+ \text { Risk Country }+ \text { Risk Scoring }
$$

Where,

$$
\begin{aligned}
\text { Risk country }= & \text { risks of foreign investment in Indonesia } \\
\text { Risk scoring }= & \text { the risk of upstream oil and gas project by } \\
& \text { location, activity and type of drilling }
\end{aligned}
$$

Risks should be accounted for in this regard is the risk based on type of project activity ${ }^{7}$, the risk based on project location $^{8}$, the risk based on type of drilling. ${ }^{9}$ The range of upstream oil and gas project risk in Indonesia based on activity, location, and drilling that is was calculated by Analytical Hierarchy Process by can be found in Figure 1 .

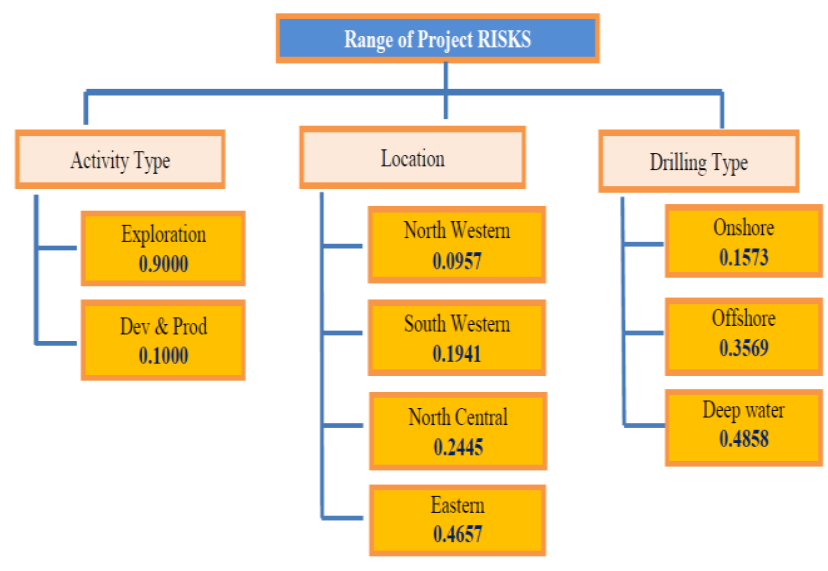

Fig. 1. Matrix range of upstream oil and gas projects risk in Indonesia ${ }^{6}$

The Static DCF models include a sensitivity analysis using the input variables are varied to determine its effect on NPV. ${ }^{10}$ Through this analysis would be known variation NPV value that occurs due to alter in value of its variable input (such as commodity prices, capital expenditures, operational expenditures and MARR) on the reference case scenario ceteris paribus.

\section{B. The Pattern of Cash Flows Upstream Oil And Gas Projects In Indonesia}

Cash flow of the parties in the upstream oil and gas projects in Indonesia without investment credit can be seen on Figure 2.

The government's cash flow is cash in flow on after the production phase consists of the government's share of the First Tranche Petroleum (FTP) and Equity to Be Split (ETBS), Domestic Market Obligation (DMO), taxes, and deducting DMO fee.

Contractor's cash flow are divided into cash flow at the stages of exploration and development and cash flow at the production stage. Cash flow on the exploration phase and development phase are expenses such as legal fees, tender, seismic and G\&G studies, exploration drilling, exploration administration, development cost (development drilling, 
production facilities, general administration) and other costs. Contractor cash flow at the production stage consists of the cash in and cash out are taken into account during the current year. Contractor Cash in flow are contractor's share of the FTP and ETS, cost recovery, DMO fee, and Investment credit (if governed by the contract). While cash-out covers all of expenses such as DMO, taxes, the additional capital expenses i.e work overrun well and operational expenses.

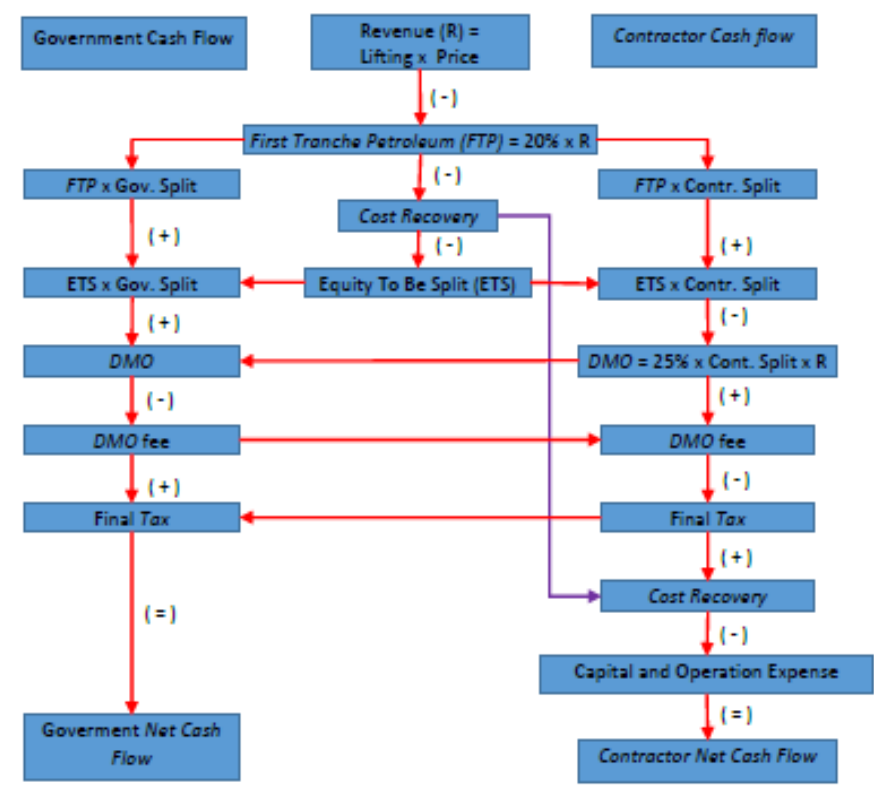

Fig. 2. Schematic cash flow at psc upstream oil and gas projects in indonesia ${ }^{1}$

\section{METHODOLOGY}

This study uses a static DCF methods (PoD version and modified version) to enumerate the interest value of "AAX" oil field project on the valuation date of December $31^{\text {th }}, 2015$. In the calculation of the price of "AAX" crude oil was considered the same as the price of belanak crude oil. "AAX" and belanak crude oil was a kind of crude oil that extracted from the same basin.

DCF version PoD was static DCF based on the submission rules of Plan of Development (PoD). This model use the average price of the last five years Indonesian Crude oil Price as the future price and single discount factor, $10 \%$ as minimum attractive rate of return (MARR) for the calculation of project cash flow. The calculation of the modified DCF model use the long-term price estimated an existing in the World Oil Outlook 2015, Organization of Petroleum Exporting Countries (OPEC). MARR is calculated from the company's WACC plus additional risk based on location, type of activity and the type of drilling. Therefore, investments and transactions are conducted in US dollar denomination, so that the risk country is negligible.

Project duration is 30 years, starting from December 12, 2004 until December 11, 2034. For simplicity it was assumed to time of the contract effectively began in 2005 , so that the time index by 2005 was $t=-10$, time index for the year of valuation date, 2015 was $\mathrm{t}=0$ and end of contract, 2034 was $\mathrm{t}$ $=19$ (see Figure 3$)$

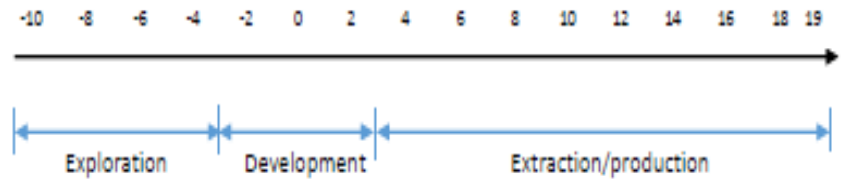

Fig. 3. time Scheme of "AAX" oil field project valuation

From Figure III it is known that spending on exploration activity has been going on at time $t=-10$ to $t=-4$. Spending on construction and development has occurred at $\mathrm{t}=-3$ up to $\mathrm{t}=4$ and revenues will be received in early 2019, when $\mathrm{t}=4$.

\section{RESULTS AND DISCUSSION}

\section{A. Estimated Financing Plan and The Imposition of Cost Recoverable}

The "AAX" Oil field located in West "NTX" Basin (North Western) which has a depth of $73 \mathrm{~m}$ below the sea surface (offshore drilling type). The production patterns of "AAX" oil field indicates during the contract period may be lifted crude a number of 100,76 MMstb (Mile Mile Standard tonk barrel that's mean million standard tonk barrel). $82 \%$ of the amount produced $(82,67 \mathrm{MMStb})$ will be produced in the first half period of commercial production (see Table II). This field contains reserves of heavy oil only without gas content or water. The contractor who have the interest of the project at this time is "AX" Ltd and "STX" Ltd, with operatorship rights rests with "STX" Ltd

TABLE II. THE PRODUCTION PATTERNS OF “AAX” OIL FIELD

\begin{tabular}{|c|c|c|c|}
\hline \multirow{2}{*}{ Years } & \multicolumn{3}{|c|}{ Production } \\
\cline { 2 - 4 } & $\begin{array}{c}\text { Daily, } \\
\text { MBOPD }\end{array}$ & $\begin{array}{c}\text { Yearly, } \\
\text { MMstb }\end{array}$ & $\begin{array}{c}\text { Cumulative, } \\
\text { MMstb }\end{array}$ \\
\hline 4 & 25 & 9,13 & 9,13 \\
\hline 5 & 31 & 11,32 & 20,44 \\
\hline 6 & 40 & 14,6 & 35,04 \\
\hline 7 & 40 & 14,6 & 49,64 \\
\hline 8 & 35 & 12,78 & 62,42 \\
\hline 9 & 24 & 8,76 & 71,18 \\
\hline 10 & 18 & 6,57 & 77,75 \\
\hline 11 & 13,5 & 4,93 & 82,67 \\
\hline 12 & 10,5 & 3,83 & 86,5 \\
\hline 13 & 8,8 & 3,21 & 89,7 \\
\hline 14 & 7,4 & 2,7 & 92,42 \\
\hline 15 & 6,3 & 2,3 & 94,72 \\
\hline 16 & 5,7 & 2,08 & 96,8 \\
\hline 17 & 5 & 1,83 & 98,62 \\
\hline 18 & 4,5 & 1,64 & 100,27 \\
\hline 19 & 4,1 & 0,5 & 100,76 \\
\hline
\end{tabular}




\section{Aruments PRESS}

Production sharing scheme between the contractor and the government before tax (split gross) with final tax rate $44 \%$ is $26,7857 \%$ and $73,2143 \%$.

Table III presents the estimated financing plan and the imposition of cost recoverable "AAX" oil field for the lifetime the project expected to reach MUS \$ 1.455.577 (thousand U.S Dollars) .

TABLE III. THE AMOUNT OF EXPENDITURE AND THE IMPOSITION OF COST RECOVERABLE OF “AAX” OIL FIELD PROJECT

\begin{tabular}{|c|c|c|c|c|c|c|c|}
\hline \multirow{2}{*}{$\begin{array}{l}\text { Time } \\
\text { index }\end{array}$} & \multicolumn{5}{|c|}{ Cash Out, MUS \$ } & \multicolumn{2}{|c|}{$\begin{array}{c}\text { Cost recoverable, } \\
\text { MUS \$ }\end{array}$} \\
\hline & $\begin{array}{l}\text { Sunk } \\
\text { Cost }\end{array}$ & Capex & Opex & Total & $\begin{array}{l}\text { Cumu } \\
\text { lative }\end{array}$ & $\begin{array}{c}\text { The } \\
\text { Imposition }\end{array}$ & $\begin{array}{l}\text { Cumu } \\
\text { lative }\end{array}$ \\
\hline-10 & 6.140 & - & - & 6.140 & 6.140 & - & - \\
\hline-9 & 6.645 & - & - & 6.645 & 12.785 & - & - \\
\hline-8 & 5.455 & - & - & 5.455 & 18.240 & - & - \\
\hline-7 & 2.790 & - & - & 2.790 & 21.030 & - & - \\
\hline-6 & 2.280 & - & - & 2.280 & 23.310 & - & - \\
\hline-5 & 1.930 & - & - & 1.930 & 25.240 & - & - \\
\hline-4 & 1.520 & - & - & 1.520 & 26.760 & 25.560 & 25.560 \\
\hline-3 & - & 3.090 & - & 3.090 & 29.850 & 3.090 & 28.650 \\
\hline-2 & - & 4.710 & - & 4.710 & 34.560 & 4.710 & 33.360 \\
\hline-1 & - & 10.990 & - & 10.990 & 45.550 & 10.990 & 44.350 \\
\hline 0 & - & 13.270 & - & 13.270 & 58.820 & 13.270 & 57.620 \\
\hline 1 & - & 165.250 & - & 165.250 & 224.070 & 5.250 & 62.870 \\
\hline 2 & - & 118.250 & - & 118.250 & 342.320 & 34.250 & 97.120 \\
\hline 3 & - & 147.650 & - & 147.650 & 489.970 & 215.700 & 312.820 \\
\hline 4 & - & 24.000 & 35.861 & 59.861 & 549.831 & 103.849 & 416.669 \\
\hline 5 & - & 24.000 & 39.171 & 63.171 & 613.002 & 96.162 & 512.830 \\
\hline 6 & - & 24.000 & 42.205 & 66.205 & 679.207 & 119.424 & 632.254 \\
\hline 7 & - & 24.000 & 45.054 & 69.054 & 748.260 & 94.730 & 726.984 \\
\hline 8 & - & 24.000 & 44.338 & 68.338 & 816.598 & 88.414 & 815.398 \\
\hline 9 & - & 35.090 & 42.848 & 77.938 & 894.536 & 74.943 & 890.341 \\
\hline 10 & - & 24.000 & 44.115 & 68.115 & 962.650 & 68.863 & 959.204 \\
\hline 11 & - & 34.900 & 45.409 & 80.309 & 1.042 .959 & 77.927 & 1.037 .132 \\
\hline 12 & - & 24.000 & 46.402 & 70.402 & 1.113 .360 & 71.558 & 1.108 .690 \\
\hline 13 & - & 34.900 & 47.093 & 81.993 & 1.195 .354 & 79.918 & 1.188 .608 \\
\hline 14 & - & - & 47.910 & 47.910 & 1.243 .264 & 50.007 & 1.238 .615 \\
\hline 15 & - & - & 48.344 & 48.344 & 1.291 .607 & 49.206 & 1.287 .821 \\
\hline 16 & - & - & 48.665 & 48.665 & 1.340 .272 & 50.010 & 1.337 .831 \\
\hline 17 & - & - & 49.285 & 49.285 & 1.389 .558 & 49.596 & 1.387 .426 \\
\hline 18 & - & - & 49.414 & 49.414 & 1.438 .972 & 50.345 & 1.437 .772 \\
\hline 19 & - & - & 16.606 & 16.606 & 1.455 .578 & 16.606 & 1.454 .378 \\
\hline & & & & 1.455 .578 & & 1.454 .378 & \\
\hline
\end{tabular}

$B$. The calculation of the value of projects interest using static methods of DCF

Based on the current project guidelines namely the rules of of the BP MIGAS No. 0072/ BP0000/2010/S0 the year 2010, hurdle rate or the Minimum Attractive Rate of Return (MARR) for the calculation of DCF version PoD are specified of using single value of $10 \%$ for the lifetime the project. Meanwhile "AAX" oil price assumption determined by the average price of belanak crude oil of the past five years amounted to US \$ 89,41/bbl (barrel).

On the other hand the input data for setting as a MARR of modified model of DCF are as follows:

- Risk free rate are 3,22\% (-10 $\leq \mathrm{t} \leq-1)$ and 3,81\% (0 $\leq$ $\mathrm{t} \leq 19)$

- Beta of "AX" Itd is 1,29 and "STX" Ltd is 1,67

- Cost of debt "AX" Ltd and "STX" Ltd are 3,97\% and $4,54 \%$

- Cost of capital "AX" Ltd prior and after the valuation date are $18,09 \%(-10 \leq \mathrm{t} \leq-1)$ and $18,68 \%(0 \leq \mathrm{t} \leq 19)$

- Cost of capital "STX" Ltd prior and after the valuation date are $14,71 \%(-10 \leq \mathrm{t} \leq-1)$ and $15,29 \%(0 \leq \mathrm{t} \leq$ 19)

- Indonesian market risk premium $8,9 \%{ }^{10}$

- Company's tax rate $40 \%$

- WACC of "STX" Ltd prior and after the valuation date are $11,61 \%$ and $11,96 \%$

- WACC of "AX" Ltd before and after the the valuation date are $12,62 \%$ and $13,11 \%$

Subsequently risk scoring projects are determined based on the matrix of upstream oil and gas projects project risk contained in Figure 2.1 as in the Table IV below:

TABLE IV. CALCULATION OF RISK SCORING OF "AAX" OIL FIELD PROJECT

\begin{tabular}{|c|c|c|c|c|}
\hline \multicolumn{2}{|c|}{ Aktivity Type } & Location & Drilling Type & \multirow{2}{*}{$\begin{array}{c}\text { Risk } \\
\text { scoring }\end{array}$} \\
\cline { 3 - 4 } & North Western & Offshore & \\
\hline Exploration & 0,9 & 0,0957 & 0,3569 & 0,0307 \\
\hline Dev \& Prod & 0,1 & & 0,0034 \\
\hline
\end{tabular}

So MARR of "AAX" oil field project for calculations the modified model of DCF can be calculated as in the Table V below:

TABLE V. MARR CALCULATION OF "AAX" OIL FIELD PROJECT

\begin{tabular}{|c|c|c|c|c|c|c|}
\hline \multirow{2}{*}{ Years } & \multicolumn{3}{|c|}{ WACC, \% } & \multicolumn{2}{c|}{ Risk scoring, \% } & \multirow{2}{*}{ MARR, \% } \\
\cline { 2 - 6 } & $\begin{array}{c}\text { "STX" } \\
\text { Ltd }\end{array}$ & $\begin{array}{c}\text { "AX" } \\
\text { Ltd }\end{array}$ & $\begin{array}{c}\text { "AAX" } \\
\text { project }\end{array}$ & $\begin{array}{c}\text { Explora } \\
\text { tion }\end{array}$ & $\begin{array}{c}\text { Dev \& } \\
\text { Prod }\end{array}$ & \multirow{2}{*}{ MAR } \\
\hline $2005-2010$ & 11,61 & 12,62 & 12,12 & 3,07 & & 15,19 \\
\hline $2011-2015$ & 11,61 & 12,62 & 12,12 & & 0,34 & 12,46 \\
\hline $2016-2034$ & 11,96 & 13,11 & 12,53 & & 0,34 & 12,87 \\
\hline
\end{tabular}




\section{Arineris PRESS}

Forecasting the future of oil prices in the modified model of DCF refers to Long-term forecasts average prices of Opec Reference Basket Price (ORB Price) implied in World Oil Outlook 2015 (WOO-2015). Based on the historical data is known that an average price Belanak US \$2,54/bbl is lower than ORB Price. So the formula to predict Belanak oil prices is ORB price estimate - US \$2.45/bbl. Estimates of annual average price of belanak crude oil based on ORB price projection from 2016 until 2034 could be seen in the Table VI below:

TABLE VI. PROJECTED ANNUAL AVERAGE PRICE OF BELANAK CRUDE OIL IN US \$/BBL.

\begin{tabular}{|c|c|c|}
\hline Year & ORB Price & Belanak \\
\hline 2016 & 60 & 57,5 \\
\hline 2017 & 65 & 62,5 \\
\hline 2018 & 70 & 67,5 \\
\hline 2019 & 75 & 72,5 \\
\hline 2020 & 80 & 77,5 \\
\hline 2021 & 85 & 82,5 \\
\hline 2022 & 90 & 87,5 \\
\hline 2023 & 95 & 92,5 \\
\hline 2024 & 99 & 96,5 \\
\hline 2025 & 103 & 100,5 \\
\hline 2026 & 107 & 104,5 \\
\hline 2027 & 111 & 109 \\
\hline 2028 & 115 & 113 \\
\hline 2029 & 119 & 117 \\
\hline 2030 & 123 & 121 \\
\hline 2031 & 127 & 124,5 \\
\hline 2032 & 131 & 129 \\
\hline 2033 & 135 & 133 \\
\hline 2034 & 139 & 137 \\
\hline
\end{tabular}

The results of the PoD model of DCF calculations generate total revenue MUS S 9,008.409 and value of project interest of "AAX" oil field MUS \$ 367,860. Meanwhile modified model of DCF produces total revenue MUS S 9.369.968 and value of project interest of "AAX" oil field MUS \$222.775. So there is a difference amount of MUS \$ 145.095 between both of them.

Whereas the oil price assumptions difference between the two models DCF did not cause a large difference in the total value of the project revenue. DCF version PoD result total revenue amount MUS \$ 9.008.409 and DCF version Modification produce total revenue amount MUS \$ 9.369.968 throughout the project life. Likewise, during the first five years of production, the DCF version POD generate total revenue of MUS \$ 5.580.327 and the DCF version modification model produces total revenue of MUS \$ 5.202.164 at the same period.

So DCF version PoD produce higher value of interest because using the discount factor is lower than the DCF version Modification. It due to the DCF model modification judging this project is more risky by into account the project risks based on the activity, type of drilling and location.

Although these two models generate positive cash flow during the production period, but after a year to 12 its value is much decreased (see Table VII). This decrease is logical because of the production patterns known until in the year to 12 have produced as many as 86,51 MMSTB of total 100.76 MMSTB crude oil that can be extracted during the contract period.

TABLE VII. REVENUE, NET CASH FLOW PRESENT VALUE AND VALUE OF PROJECT INTEREST THE "AAX" OIL FIELD

\begin{tabular}{|c|c|c|c|c|c|c|}
\hline \multirow{3}{*}{$\begin{array}{l}\text { Time } \\
\text { Index }\end{array}$} & \multicolumn{3}{|c|}{ DCF Version $\mathrm{PoD}$} & \multicolumn{3}{|c|}{ DCF V ersion Modification } \\
\hline & \multirow{2}{*}{$\begin{array}{c}\text { Project } \\
\text { Revenue, } \\
\text { MUS S }\end{array}$} & \multicolumn{2}{|c|}{$\begin{array}{c}\text { PV of Contractor NCF, } \\
\text { MUS S }\end{array}$} & \multirow{2}{*}{$\begin{array}{c}\text { Project } \\
\text { Revenue, } \\
\text { MUS S }\end{array}$} & \multicolumn{2}{|c|}{$\begin{array}{c}\text { PV of Contractor NCF, } \\
\text { MUS } S\end{array}$} \\
\hline & & yearly & Cumulative & & yearly & Cumulative \\
\hline-10 & - & $(15926)$ & $(15.926)$ & - & $(25.252)$ & $(25252)$ \\
\hline-9 & - & $(15.669)$ & $(31.594)$ & - & $(23.725)$ & $(48.977)$ \\
\hline-8 & - & $(11.693)$ & $(43.287)$ & - & $(16.908)$ & $(65.885)$ \\
\hline-7 & - & $(5.437)$ & $(48.724)$ & - & $(7.507)$ & $(73.392)$ \\
\hline-6 & - & $(4.039)$ & $(52.763)$ & - & $(5.326)$ & $(78.718)$ \\
\hline-5 & - & $(3.108)$ & $(55.872)$ & - & (3.914) & $(82.632)$ \\
\hline-4 & - & $(2.225)$ & $(58.097)$ & - & $(2.431)$ & $(85.063)$ \\
\hline-3 & - & $(4.113)$ & $(62.210)$ & - & $(4.395)$ & $(89.458)$ \\
\hline-2 & - & $(5.699)$ & $(67.909)$ & - & $(5.957)$ & $(95.415)$ \\
\hline-1 & - & $(12.089)$ & (79.998) & - & $(12.359)$ & $(107.774)$ \\
\hline 0 & - & $(13270)$ & $(93.268)$ & - & $(13.270)$ & (121.044) \\
\hline 1 & - & $(150.227)$ & $(243.495)$ & - & $(146.403)$ & $(267.447)$ \\
\hline 2 & - & $(97.727)$ & (341.223) & - & $(92.815)$ & $(360.262)$ \\
\hline 3 & - & $(110.932)$ & $(452.154)$ & - & $(102.674)$ & $(462.936)$ \\
\hline 4 & 815.837 & 284.600 & $(167.554)$ & 661.563 & 242.452 & $(220.484)$ \\
\hline 5 & 1.011 .638 & 105.750 & $(61.804)$ & 876.913 & 81.928 & $(138.556)$ \\
\hline 6 & 1.305 .340 & 130.454 & 68.650 & 1204.500 & 104.441 & $(34.115)$ \\
\hline 7 & 1.305 .340 & 106.361 & 175.011 & 1277.500 & 87.007 & 52.892 \\
\hline 8 & 1.142 .172 & 83.103 & 258.114 & 1.181 .688 & 69.863 & 122.755 \\
\hline 9 & 783.204 & 34212 & 292.326 & 845.340 & 29.594 & 152.349 \\
\hline 10 & 587.403 & 23.904 & 316.230 & 660.285 & 21.036 & 173.385 \\
\hline 11 & 440.552 & 14.179 & 330.409 & 514.924 & 12.996 & 186.381 \\
\hline 12 & 342.652 & 10.572 & 340.981 & 415.826 & 9.780 & 196.161 \\
\hline 13 & 287.175 & 6.490 & 347.471 & 361.350 & 6.457 & 202.618 \\
\hline 14 & 241.488 & 6.508 & 353.980 & 314.667 & 6.123 & 208.741 \\
\hline 15 & 205.591 & 4.629 & 358.608 & 277.090 & 4.517 & 213.258 \\
\hline 16 & 186.011 & 3.789 & 362.397 & 259.022 & 3.751 & 217.009 \\
\hline 17 & 163.167 & 2.716 & 365.113 & 234.513 & 2.827 & 219.836 \\
\hline 18 & 146.851 & 2.218 & 367.331 & 217.631 & 2.340 & 222.176 \\
\hline \multirow[t]{2}{*}{19} & 43.988 & 529 & 367.860 & 67.158 & 598 & 222.775 \\
\hline & 9.008 .409 & 367.860 & & 9.369 .968 & 222.775 & \\
\hline
\end{tabular}


The sensitivity analysis against the value of project interest on calculation results of the DCF version PoD done by altering the price, capital expenditures (capex) and operational expenditures (opex) on the reference case scenario ceteris paribus. The results of the sensitivity analysis indicates the value of project interest is highly sensitive to changes in crude oil prices. The decline in oil prices of $60 \%$ of the reference price case cause the value interest decreased to MUS \$ -2.193. This is a decrease of $100,6 \%$ of the initial values MUS \$ 367.860 (see Table VIII and Figure 4)

TABLE VIII. THE SENSITIVITY ANALYSIS ON THE VALUE OF PROJECT INTEREST OF DCF VERSION POD FOR OIL PRICE, CAPEX TARGETS, OPEX TARGETS.

\begin{tabular}{|c|c|c|c|c|c|c|c|}
\hline \multicolumn{2}{|c|}{ Price, $\%$ Change } & $-60 \%$ & $-40 \%$ & $-20 \%$ & $20 \%$ & $40 \%$ & $60 \%$ \\
\hline \multirow{2}{*}{$\begin{array}{l}\text { Interest } \\
\text { Value }\end{array}$} & MUS \$ & $(2.193)$ & 125.908 & 247.545 & 88.174 & 608.489 & 728.803 \\
\hline & \%Change & $-100,60$ & $-65,77$ & $-32,71$ & 32,71 & 65,41 & 98,12 \\
\hline \multicolumn{2}{|c|}{ Capex, \% Change } & $-60 \%$ & $-40 \%$ & $-20 \%$ & $20 \%$ & $40 \%$ & $60 \%$ \\
\hline \multirow{2}{*}{$\begin{array}{l}\text { Interest } \\
\text { Value }\end{array}$} & MUS \$ & 462.038 & 430.645 & 399.252 & 336.467 & 305.074 & 273.681 \\
\hline & $\%$ Change & 25,60 & 17,07 & 8,53 & $-8,53$ & $-17,07$ & $-25,60$ \\
\hline \multicolumn{2}{|c|}{ Opex, \% Change } & $-60 \%$ & $-40 \%$ & $-20 \%$ & $20 \%$ & $40 \%$ & $60 \%$ \\
\hline \multirow{2}{*}{$\begin{array}{l}\text { Interest } \\
\text { Value }\end{array}$} & MUS \$ & 387.954 & 381.256 & 374.558 & 361.161 & 354.463 & 347.765 \\
\hline & $\%$ Change & 5,46 & 3,64 & 1,82 & $-1,82$ & $-3,64$ & $-5,46$ \\
\hline
\end{tabular}

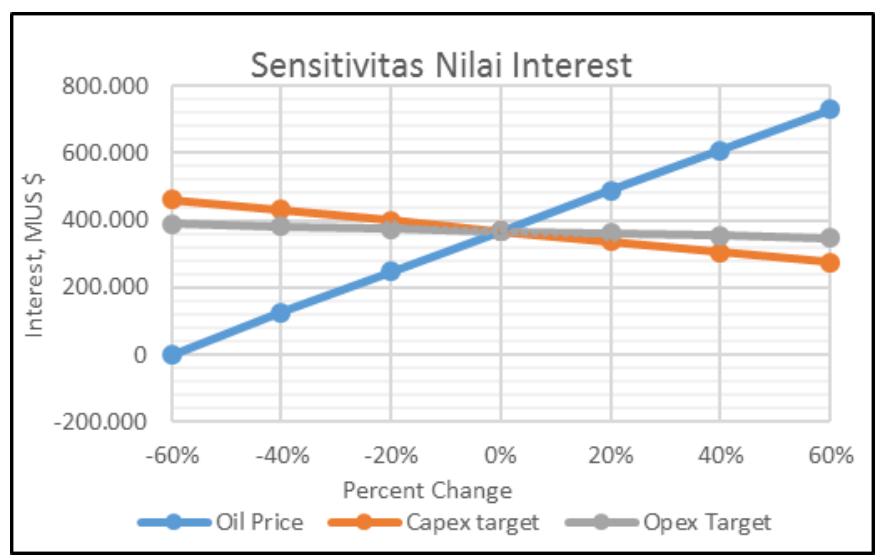

Fig. 4. Graph of the sensitivity of interest value towards price changes, capex targets and opex targets.

Besides oil prices, capex targets, and the opex targets, the change of MARR also have a major influence on the interest value. The changes to the company's capital structure, risk free rate, and the beta will alter the value of MARR. Table IX, Figure V and Figure VI presents sensitivity analysis on interest project value of the DCF version Modification to changes in oil prices, capex targets, opex targets and MARR.
TABLE IX. SENSITIVITY ANALYSIS ON VALUE OF PROJECT INTEREST OF THE MODIFIED DCF MODEL FOR OIL PRICE, CAPEX TARGETS, OPEX TARGETS AND MARR

\begin{tabular}{|c|c|c|c|c|c|c|c|}
\hline \multicolumn{2}{|c|}{ Price, $\%$ Change } & $-60 \%$ & $-40 \%$ & $-20 \%$ & $20 \%$ & $40 \%$ & $60 \%$ \\
\hline \multirow{2}{*}{$\begin{array}{c}\text { Interest } \\
\text { Value }\end{array}$} & MUS \$ & $(82.546)$ & 22.193 & 125.444 & 320.106 & 417.437 & 514.769 \\
\hline & $\%$ Change & $-137,05$ & -90 & -44 & 44 & 87 & 131 \\
\hline \multicolumn{2}{|c|}{ Capex, \% Change } & $-60 \%$ & $-40 \%$ & $-20 \%$ & $20 \%$ & $40 \%$ & $60 \%$ \\
\hline \multirow{2}{*}{$\begin{array}{l}\text { Interest } \\
\text { Value }\end{array}$} & MUS \$ & 322.196 & 289.056 & 255.915 & 189.634 & 154.731 & 117.347 \\
\hline & $\%$ Change & 44,63 & 29,75 & 14,88 & $-14,88$ & $-30,54$ & $-47,32$ \\
\hline \multicolumn{2}{|c|}{ Opex, \% Change } & $-60 \%$ & $-40 \%$ & $-20 \%$ & $20 \%$ & $40 \%$ & $60 \%$ \\
\hline \multirow{2}{*}{$\begin{array}{l}\text { Interest } \\
\text { Value }\end{array}$} & MUS \$ & 238.675 & 233.375 & 228.075 & 217.475 & 212.174 & 206.874 \\
\hline & $\%$ Change & 7,14 & 4,76 & 2,38 & $-2,38$ & $-4,76$ & $-7,14$ \\
\hline \multicolumn{3}{|c|}{ MARR Value } & $6,87 \%$ & $9,87 \%$ & $15,87 \%$ & $17,87 \%$ & $19,87 \%$ \\
\hline \multirow{2}{*}{$\begin{array}{c}\text { Interest } \\
\text { Value }\end{array}$} & \multicolumn{2}{|c|}{ MUS \$ } & 477.656 & 333.695 & 136.219 & 88.964 & 48.445 \\
\hline & \multicolumn{2}{|c|}{ \%Change } & 114,41 & 49,79 & $-38,85 \%$ & -60 & $-78,25$ \\
\hline
\end{tabular}

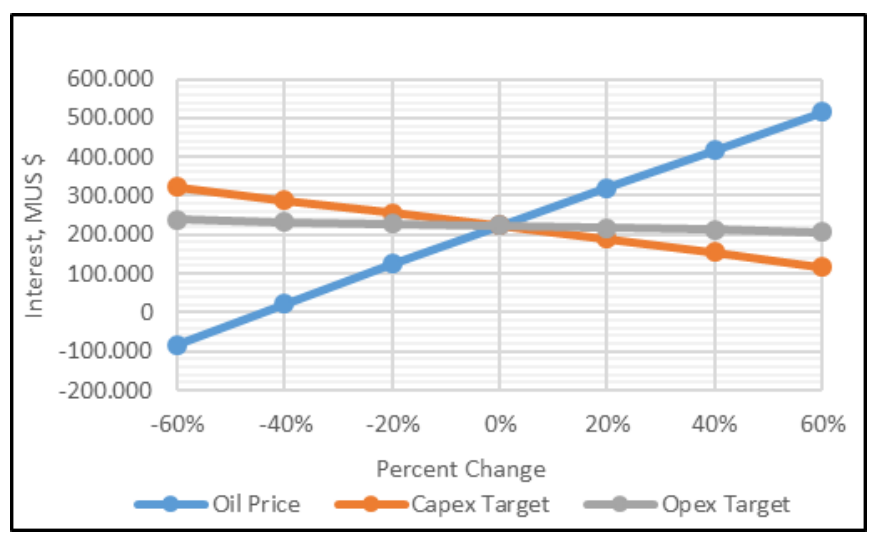

Fig. 5. Graph of the sensitivity of interest value towards price changes. capex targets and opex targets

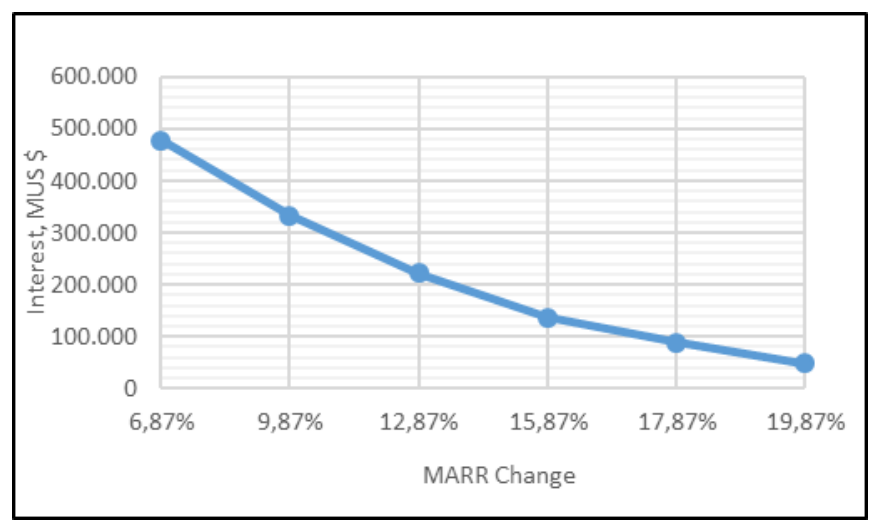

Fig. 6. Graph of the sensitivity of interest value towards MARR change 
The sensitivity analysis on the results of the DCF version Modification shows the interest value is sensitive to changes in oil prices and the MARR. If the price of oil down $60 \%$ from the initial price, then the interest value would fall to MUS \$ 82.546. This Figure is a decrease of $104 \%$ of the interest the initial value of MUS $\$ 222.775$. But the price reduction of $40 \%$ of the reference case is still generating positive interest value of MUS \$22,193. While the increase in MARR into $19.87 \%$ of the initial value of $12.87 \%$ will decrease in interest value by $78.25 \%$ to MUS \$ 48.455

\section{CONCLUSION \& SUGGESTIONS}

As discussed previously, DCF version PoD that uses a single value of MARR generate higher interest value than DCF version Modifications. The main cause of this difference is the DCF model modification MARR that is higher than the DCF pod because it takes into project risk scoring based on activity, drilling type and project location.Therefore the value of MARR that is used DCF version Modification is better illustrate the actual risk, ${ }^{6}$ inferred value of interest of this project is MUS \$ 222.775 (based on the results of the DCF model modification).

From the results of the sensitivity analysis are known interest value of the project is sensitive to changes in oil prices and the minimum attractive rate of return. The value of project interest which is sensitive to changes in MARR, causing the single value of MARR of $10 \%$ for all conditions tend to generate less precise value. So MARR should be calculated based on market conditions and risks of the project based on location, type of activity and drilling. Therefore it is advisable to Special Task Force for Upstream Oil and Gas Business Activities to consider the use of different discount rates according to the type of drilling, project activity and locations on the DCF method in the calculation of the value of the project.

Although this study shows the value of the oil field project interest "AAX" is positive, but the pattern of annual cash flow stating this project would not be sufficiently profitable after the year to 12 . These results imply this project must assess the application of technology enhanced oil recovery (EOR) for optimize the amount of oil extracted in the year 13 to the end of the project.

\section{REFERENCES}

[1] Pudyantoro, A. R. (2014) Proyek Hulu Migas. Evaluasi dan Analisis PetroEkonomi, Petromindo. Jakarta.

[2] Organization of the Petroleum Exporting Countries - OPEC. (2016) Monthly Oil Market Report - January 2016, OPEC Secretariat. Vienna

[3] Durden, T., (2016). Oils's Casualty: Saudi Binladin Group Fires 50.000, A Quarter of Its Workforce. Retrieved April 30, 2016 from http://www.zerohedge.com/news/a2016-04-30/oils-latest-casualty-saudibinladin-grup-fires-50000-workers-quqrter-its-workforce.

[4] Wijayanto, N. (2015) Target Eksplorasi Migas Diturunkan, Retrieved $\begin{array}{lll}\text { September } & 25, & \text { from, }\end{array}$ http://ekbis.sindonews.com/read/1003979/150/target-eksplorasi-migasditurunkan-1432258054

[5] Damodaran, A. (2006) Damodaran on Valuation. Security Analysis for Investment and Corporate Finance, 2rd Edition, Jhon Willey \& Son, Inc. New Jersey
[6] Liana, L. (2004) Using Analyticical Hierarchy Process To Determine Appropriate Minimum Attractive Rate of Return for Oil and Gas Projects In Indonesia. PM World Journal Vol III, Issue II

[7] Wright, C.J., Gallun, R.A., (2008). Fundamental Oil and Gas Accounting. $5^{\text {th }}$ Edition, PennWell Corporation, Tulsa, Oklahoma

[8] Price Waterhouse Coppers. (2012) Staring Down the Barrel. An investor survey of the Indonesian oil and gas industry

[9] Rouzaut, N.B., Favennec, J.P. (2007) Oil and Gas Exploration and Production : Reserves, Costs, Contracts. Third Edition, Editions Technip. Centre for Economics and Management, Paris

[10] Kodukula, P. and Papudesu, C. (2006) Project Valuation Using Real Options : A Practitioner's Guide, J. Ross Publishing. Fort lauderdale, Florida

[11] Fernandez, P., Ortiz, A., Acin, I.F., (2015). Market Risk Premium and Risk Free Rate Used For 41 Countries in 2015. Retrieved November 19, 2015 from: http://ssrn.com/abstract=2598104

interest recovery, if it was set in the contract 